\title{
Does tighter perioperative glycemic control improve outcomes for diabetic patients undergoing coronary artery bypass graft surgery?
}

Lazar HL, Chipkin SR, Fitzgerald CA, Bao Y, Cabral H, Apstein CS. Tight glycemic control in diabetic coronary artery bypass graft patients improves perioperative outcomes and decreases recurrent ischemic events. Circulation 2004;109:1497-502.

Background: Patients with diabetes mellitus undergoing coronary artery bypass graft surgery (CABG) have increased perioperative morbidity and mortality. ${ }^{1}$ Tighter glycemic control with an insulin infusion immediately after an acute myocardial infarction has been found to reduce mortality among patients with hyperglycemia. ${ }^{2}$ It is unknown whether diabetic patients undergoing CABG would also benefit from tighter glycemic control.

Design: In a randomized controlled trial, 141 diabetic patients undergoing CABG were assigned to receive either glucose-insulin-potassium infusion (GIK group) or conventional therapy with subcutaneous in$\infty$ sulin (non-GIK group). In the GIK group, patients were given $500 \mathrm{~mL}$ of $5 \%$ dextrose in water $\left(D_{5} W\right)$ mixed with 80 units of regular insulin and $40 \mathrm{mmol}$ of potassium chloride infused at $30 \mathrm{~mL} / \mathrm{h}$ immediately preopera-

hours postoperatively and titrated to achieve a target glucose level of $6.9-11.1 \mathrm{mmol} / \mathrm{L}$. The non-GIK group received $\mathrm{D}_{5} \mathrm{~W}$ infused at $30 \mathrm{~mL} / \mathrm{h}$ and subcutaneous insulin injections according to a sliding scale to achieve a target glucose level of $<13.9 \mathrm{mmol} / \mathrm{L}$ ).

Results: The 2 groups were similar at baseline. Compared with the non-GIK group, the GIK group achieved significantly better glycemic control throughout the study period and had improved postoperative outcomes (Table 1). Kaplan-Meier curves showed a survival advantage for the GIK group over the first 2 years after surgery $(p=0.04)$.

Commentary: The results of this well-conducted randomized controlled trial suggest that tighter, early perioperative glycemic control (target glucose $<11.1 \mathrm{mmol} / \mathrm{L}$ ) with GIK infusion improves postoperative outcomes and long-term morbidity and mortality among patively and continued for 12

Table 1: Postoperative outcomes of diabetic patients undergoing CABG with or without tight perioperative glycemic control with a GIK solution*

\begin{tabular}{lccc}
\hline & GIK group \\
Variable & $n=72$ & $\begin{array}{c}\text { Non-GIK group } \\
n=69\end{array}$ & $p$ value \\
\hline Pacing, no. (\%) of patients & $10(14)$ & $27(39)$ & 0.001 \\
Atrial fibrillation, no. (\%) of patients & $12(17)$ & $29(42)$ & 0.002 \\
Infections, no. (\%) of patients & 0 & $9(13)$ & 0.01 \\
Time on ventilator, mean (SEM), h & $6.9(0.3)$ & $10.7(0.6)$ & 0.0002 \\
Inotropic score, mean (SEM) & $1.18(0.06)$ & $2.16(0.18)$ & 0.001 \\
Length of stay in ICU, mean (SEM), h & $17.3(1.0)$ & $32.8(2.6)$ & 0.001 \\
Length of postoperative hospital stay, mean (SEM), d & $6.5(0.1)$ & $9.2(0.3)$ & 0.003 \\
5-yr follow-up, no. (\%) of patients & & $7(1)$ & $13(19)$ \\
$\quad$ Recurrent sternal or leg infections & $4(5)$ & $44 / 54(81)$ \\
$\quad$ Recurrent ischemia & $56 / 59(95)$ & 0.03 \\
$\quad$ Angina class 0 & & $1(1)$ \\
\hline
\end{tabular}

Note: $\mathrm{CABG}=$ coronary artery bypass grafting, GIK = glucose-insulin-potassium, SEM = standard error of the mean. tients with diabetes undergoing CABG. The finding that improved glycemic control with an insulin infusion confers cardiovascular benefits is consistent with results from a retrospective study of diabetic patients undergoing $\mathrm{CABG}^{1}$ and a prospective study of patients with acute myocardial infarction.

Proposed mechanisms through which these benefits may occur include improved endothelial function, improved myocardial metabolism, decreased inflammatory markers and reduced thrombogenicity. ${ }^{2}$ It remains unclear whether these benefits result from the improved glycemic control, the GIK infusion itself or both. Of interest, the outcome benefits in this study were demonstrated even though the GIK infusion was continued for only 12 hours postoperatively.

A critical question remains: Can tight glycemic control benefit patients with diabetes undergoing other types of surgery? The benefits seen in this study were largely, although not exclusively, of a cardiac nature and may not be seen with noncardiac procedures. However, the study's results are consistent with those from a study by van den Berghe and colleagues, ${ }^{3}$ which suggest that intensive glycemic control is beneficial to all postoperative patients with hyperglycemia who require mechanical ventilation. Therefore, although the current study addressed only CABG, the benefits may be more widely applicable to other groups of surgical patients with diabetes.

Practice implications: Tight glycemic control (serum glucose $<11.1 \mathrm{mmol} / \mathrm{L}$ ) with a GIK infusion should be instituted in diabetic patients un- 
dergoing CABG, beginning preoperatively and continued for at least 12 hours postoperatively. Once the patient has been transferred to the intensive care unit (ICU) tighter glycemic control (serum glucose 4.5-6.0 mmol/L) with continuous insulin infusion should be instituted, as recommended in the 2003 Canadian Diabetes Association clinical practice guidelines. ${ }^{4}$ The infusion should be accompanied by a source of glucose and possibly potassium for the first 12 hours after admission to the ICU. Serum glucose and potassium levels should be closely monitored during the infusion.

\section{Alice Y.Y. Cheng}

Division of Endocrinology and Metabolism

St. Michael's Hospital

Department of Medicine

University of Toronto

Toronto, Ont.

\section{References}

1. Furnary AP, Gao G, Grunkemeier GL, Wu Y, Zerr KJ, Bookin SO, et al. Continuous insulin infusion reduces mor- tality in patients with diabetes undergoing coronary artery bypass grafting. 7 Thorac Cardiovasc Surg 2003;125(5): 1007-21.

2. Malmberg K. Prospective randomised study of intensive insulin treatment on long term survival after acute myocardial infarction in patients with diabetes mellitus. DIGAMI Study Group. BM7 1997;314:1512-5.

3. Van den Berghe G, Wouters P, Weekers F, Verwaest C, Bruyninckx F, Schetz M, et al. Intensive insulin therapy in critically ill patients. $N$ Engl f Med 2001;345(19):1359-67.

4. Canadian Diabetes Association Clinical Practice Guidelines Expert Committee. Canadian Diabetes Association 2003 clinical practice guidelines for the prevention and management of diabetes in Canada. Can 7 Diabetes 2003 ; 27(Suppl 2):S113-4.

\section{Books ReCEIVED}

Barold SS, Stroobandt RX, Sinnaeve AF. Cardiac pacemakers step by step. Malden (MA): Blackwell; 2004. 341 pp. US\$55.00 ISBN 1-4051-1647-1

Cole J. Still Lives: narratives of spinal cord injury. Cambridge (MA): The MIT Press; 2004. 330 pp. US\$27.95 ISBN 0-26203315-1

Dambro MR. 2004 Griffith's 5minute clinical consult. Philadelphia: Lippincott Willams and Wilkins; 2004. 1342 pp. US\$59.95 ISBN 0-7817-4308-7

Ellis H, Feldman S, Harrop-Griffiths $W$. Anatomy for anaesthetists. 8th ed. Malden (MA): Blackwell; 2004. 358 pp. US\$129.95 ISBN 1-4051-0663-8

Ganschow PS, Norlock FE, Jacobs EA, Marcus EA, editors. Breast health and common breast problems: a practical approach. Philadelphia: American college of Physicians; 2004. 304 pp. US\$32.00 ISBN 1-930513-22-4

Guttmacher A, Collins F, Drazen J, editors. Articles from the New England fournal of Medicine: Genomic Medicine. Baltimore: The Johns Hopkins University Press; 2004. 179 pp. US\$39.95 ISBN 0-8018-7979-5

Hayes DL, Wang PJ, SacknerBernstein J, Asirvatham SJ. Resynchronization and defibrillation for heart failure: a practical approach. Malden (MA): Blackwell;
2004; US\$60.00. 228 pp. 1-40512199-8

Knudsen S. Guide to analysis of DNA microarray data. 2nd ed. Hoboken (NJ): John Wiley and Sons; 2004. 168 pp. US\$37.95 ISBN 0-471-65604-6

Levine C, Murray TH, editors. The cultures of caregiving: conflict and common ground among families, health professionals and policy makers. Baltimore: The Johns Hopkins University Press; 2004. 187 pp. US\$35.00 ISBN 0-8018-7863-2

Mandal BK, Wilkins EGL, Dunbar EM, Mayon-White RT. Infectious diseases. 6th ed. Malden (MA): Blackwell; 2004. 267 pp. US\$39.95 ISBN 14051-0820-7

Mitton C, Donaldson C. Priority setting toolkit: a guide to the use of economics in healthcare decision making. London: BMA Books; 2004. 183 pp. $£ 19.95$ ISBN 0-7279-1736-6

Morley TP. Kenneth George McKenzie: and the founding of Neurosurgery in Canada. Markham (ON): Fitzhenry and Whiteside; 2003. 208 pp. $\$ 40.00$ 1-55041-779-7

Reuben DB, Herr KA, Pacala JT, Pollock BG, Potter JF, Semla TP. 2004 Geriatrics at your fingertips. 6th ed. Malden (MA): Blackwell; 2004. 255 pp. \$12.95 ISBN 1-4051-0443-0
Roberts D, Greenwood M. Practical food microbiology. 3rd ed. Malden (MA): Blackwell; 2003. 294 pp.US\$99.95 ISBN 14051-0075-3

Rockman HB. Intellectual property law for engineers and scientists. Hoboken (NJ): John Wiley and sons; 2004. $511 \mathrm{pp}$. US\$79.95 ISBN 0-471-44998-9

Schiller KFR, Cockel R, Warren BF. Slide atlas of gastrointestinal endoscopy and related pathology [CD-ROM]. Malden (MA): Blackwell; US\$99.95 ISBN 1-4051-1894-6

Shorvon S, Perucca E, Fish D, Dodson E, editors. The treatment of epilepsy, 2nd ed. Malden (MA): Blackwell; 2004. 913 pp. US\$225.00 ISBN 0632-06046-8

Tulandi $T$, editor. Uterine fibroids: embolization and other treatments. New York: Cambridge University Press; 2003. 147 pp. US\$95.00 ISBN 0-52181938-5

Waye JD, Rex DK, Williams CB, editors. Colonoscopy: principles and practice. Malden (MA): Blackwell; 2003. 655 pp. US\$2 65.00 ISBN 14051-1449-5

Zhang W, Shmulevich I, Astola J. Microarray quality control. Hoboken (NJ): John Wiley and Sons; 2004. 136 pp. US\$69.95 ISBN 0-471-45344-7 